\title{
BIOLOGY OF HYDRACTINIID HYDROIDS. 2. HISTOCOMPATIBILITY EFFECTOR SYSTEM/COMPETITIVE MECHANISM MEDIATED BY NEMATOCYST DISCHARGE
}

\author{
LEO W. BUSS, CATHERINE S. MCFADDEN', AND DOUGLAS R. KEENE ${ }^{2}$ \\ Department of Biology, Yale University, New Haven, Connecticut 06511
}

\begin{abstract}
Intraspecific encounters between colonies of the athecate, colonial hydroid Hydractinia echinata result in contact between mat or stolonal tissues. We have monitored colony ontogeny in five clones of $H$. echinata and initiated experimental encounters between the two tissue types in both isogeneic and allogeneic combinations. All isogeneic interactions result in fusion, all allogeneic interactions in rejection. Transmission electron microscopy shows that fusion results in the establishment of a common gastrovascular system, whereas rejection is characterized by an electrondense, fibrous layer separating the two colonies. Rejection involves either the passive cessation of growth along the contact zone or the development of hypertrophied stolons. These hyperplastic stolons destroy foreign tissues and can develop only from existing stolons. Scanning and transmission electron microscopy demonstrates that stolons become hyperplastic through the differentiation of interstitial cells into nematocytes and that the destruction of foreign tissue is effected by nematocyst discharge. Experimental elimination of interstitial cells removes the capacity of a colony to produce hyperplastic stolons, but does not affect historecognition. A comparison between these results and similar studies in anthozoans suggests the need to distinguish between the evolution of historecognition and the evolution of mechanisms of interference competition.
\end{abstract}

\section{INTRODUCTION}

Cnidarians have evolved a striking array of behavioral repertoires and morphological structures to defend their living space and expand into the space occupied by others. Scleractinian corals contacting other scleractinians extrude mesenterial filaments and actively digest their neighbors (Lang, 1971, 1973; Glynn, 1976; Sheppard, 1979). Scleractinians may also differentiate sweeper tentacles along zones of contact. These modified tentacles are armed with a specialized nematocyst population (den Hartog, 1977; Wellington, 1980) and inflict damage on neighboring colonies (Richardson $e t$ al., 1979; Sheppard, 1979; Wellington, 1980; Chornesky, 1983). Certain acontiarian sea anemones display an analogous phenomenon. Following tentacle contact between adjacent anemones, one or both individuals will differentiate catch (or 'killer') tentacles. Like sweeper tentacles, these are elongate, are heavily armed with a specialized nematocyst population (Calgren, 1929; Hand, 1955; Williams, 1975; Purcell, 1977; Watson and Mariscal, 1983), and are used to injure neighbors (Williams, 1975, 1980; Purcell, 1977; Purcell and Kitting, 1982; Watson and Mariscal, 1983). Certain endomyarian sea anemones possess acrorhagia. These structures can inflate and, upon

Received 29 March 1984; accepted 24 May 1984.

'Present address: Department of Zoology, University of Washington, Seattle, Washington 98195.

${ }^{2}$ Present address: Portland Shrine Research Unit, Shriners Hospital for Crippled Children, 3101 S. W. Sam Jackson Park Road, Portland, Oregon 97201. 
contact with the adversary, discharge nematocysts (Abel, 1954; Bonnin, 1964; Frances, 1973b; Bigger, 1976, 1980; Williams, 1978; Ottaway, 1978; Brace and Pavey, 1978; Brace, et al., 1979; Brace, 1981).

The evolution of this diverse array of structures is necessarily predicated on the existence of some underlying system of historecognition. The ability to distinguish between isogeneic, allogeneic, and xenogeneic tissues has been demonstrated in certain scleractinians (Lang, 1971, 1973; Hildeman et al., 1975, 1977a, b, 1980), actiniarians (Frances, 1973a, b, 1976; Purcell, 1977; Bigger, 1980; Brace, 1981), gorgonians (Theodor, 1970, 1976; Theodor and Senelar, 1975; Bigger and Runyan, 1979), and hydroids (Teisser, 1929; Schijfsma, 1939; Crowell, 1950; Hauenschild, 1954, 1956; Muller, 1964, 1967; Toth, 1967; Ivker, 1972; Gallien and Gouere, 1974; Tardent and Buhrer, 1982; Muller et al., 1983). It is widely assumed that histocompatibility and deployment of the various effector systems are genetically based alternatives. This assumption is supported by the common observation that aggressive devices are deployed against allogeneic tissue, but not in response to isogeneic tissue (Schijfsma, 1939; Muller, 1964, 1967; Lang, 1971, 1973; Ivker, 1972; Francis, 1973a, b, 1976; Theodor, 1976; Purcell, 1977; Bigger, 1980; Brace, 1981; Tardent and Buhrer, 1982). Genetic data, however, are available for only one cnidarian, the hydractiniid hydroid Hydractinia echinata (Hauenschild, 1954, 1956; Ivker, 1972).

Unlike anthozoans, for which there exist substantial data on the manner in which destruction of foreign tissue is effected, there is little comparable information for hydrozoans. Although instances of interspecific and intraspecific competition are known in several hydroid species (e.g., Kato et al., 1962, 1963, 1967; Chiba and Kato, 1966; Muller et al., 1983), structures specialized for competition have been described only for members of the family Hydractinidae. In $H$. echinata, fusion was first noted by Teisser (1929) between planulae derived from the same cross. Ten years later, Schijfsma (1939) noted that fusion was not the only outcome of intraspecific encounters, noting that "it looks as if the growing borders of two colonies, in striking together and checking each others progress, are stimulated by very active growth and ramifications; resulting in the formation of a dense fringe of intertwined stolons." Subsequent studies by Crowell (1950), Hauenschild (1954, 1956), and Toth (1967) discussed the lack of compatibility between colonies but did not record the behavior of tissues in contact. Muller (1964), however, reported the presence of regions of "wild" stolonal growth in contact with incompatible tissues, observing that such growth may be initiated by both of the colonies in contact. He further observed that these modified stolons were associated with the regression and subsequent demise of one of the interacting colonies and suggested that this regression is due to a toxin released by the modified stolons. Ivker (1972) expanded on Muller's observations, introducing the term "hyperplastic stolon" to describe the modification of normal stolonal growth upon contact with foreign tissue. She likewise found that hyperplastic stolons destroy foreign tissue and hypothesizes that this destruction is the result of an enzymatic secretion from hyperplastic tissue. Subsequent studies of another hydractiniid, Podocoryne carnea, have documented a similar hyperplastic response to allogeneic (Tardent and Buhrer, 1982) and xenogeneic tissues (Gallien and Gouere, 1974).

In attempt to elucidate the mechanism by which hydractiniid hydroids effect the destruction of foreign tissues, we initiated a study of the fusion-rejection interaction in H. echinata. We find (a) that mat and stolonal tissues differ in their capacity to mount a hyperplastic response, (b) that production of hyperplastic tissue is dependent on differentiation of interstitial cells, and (c) that hyperplastic tissues effect their destruction of foreign tissue by nematocyst discharge. Comparison of anthozoan and 
hydrozoan responses to foreign tissues suggests the need to distinguish between the selective forces responsible for the evolution of mechanisms of interference competition and those responsible for the evolution of historecognition.

\section{MATERIALS AND METHODS}

\section{Animal collection, maintenance and propagation}

We report on a series of laboratory investigations on the phenomenology, ultrastructure, and mechanism of the histocompatibility response in Hydractinia echinata. Methods for each topic considered here are described in separate sections below. Common to all studies, however, are the source of experimental animals and our methods of cultivation and asexual propagation.

Hydractinia echinata grows as an encrustation on the surface of gastropod shells occupied by pagurid hermit crabs (Fig. 1). The colonies of $H$. echinata used in this study were collected on a shallow subtidal $(<5 \mathrm{~m})$ gravel-mud bottom at Harrison Point, Long Island Sound, from shells occupied by Pagurus longicarpus. Colonies collected from these shells are assumed to be isogeneic. This assumption is justified because asexual propagation from one shell to another is unknown and several different attempts to detect naturally occurring chimeras have failed (McFadden et al., 1984).

Field-collected colonies were propagated by removing with a scalpel an explant of basal mat containing 1-3 feeding polyps from a shell and gently holding it to a plexiglass slide with a loop of suture thread. After 1-3 days explants attached and threads were removed. Stock colonies established in this manner were maintained in laboratory culture for a period of 2-14 months prior to this study. Colonies were maintained in a recirculating sea water system at room temperature and were fed with one-day-old brine shrimp nauplii for two hours daily. Explants from isogeneic stock colonies were attached to various experimental substrata (detailed below) for observations of colony ontogeny and histocompatibility interactions. Techniques of explantation and laboratory cultivation have been described in further detail elsewhere (Ivker, 1972; McFadden et al., 1984).

\section{Colony ontogeny, potential tissue interactions, and histocompatibility}

Colonies of $H$. echinata vary considerably in gross morphology during early ontogeny (Schijfsma, 1939; Hauenschild, 1954; Ivker, 1972; McFadden et al., 1984). The relative rates of production of mat, stolon, and polyps throughout ontogeny differ among colonies, producing a characteristic pattern in gross morphology for a given colony. Mat tissue is composed of a close network of entodermal gastrovascular canals surrounded by interstitial cells and covered by a uniform layer of ectoderm. Stolons are individual periderm-covered canals, composed of a layer of endoderm and a layer of ectoderm, which branch and anastomose to form a highly complex network crisscrossing the substratum. Feeding polyps arise from the mat (Fig. 1), and in some genotypes, from the stolons. Depending on the morphology of colonies and/or the time in ontogeny at which contact is made, there are three possible classes of interactions between isogeneic or allogeneic colonies: (1) mat contacting mat, (2) mat contacting stolon, and (3) stolon contacting stolon.

To insure observation of all possible tissue interactions, five genotypes of $\boldsymbol{H}$. echinata were chosen. The ontogeny of each colony was quantified by observing the number of polyps, the area of mat, and the area of enclosed stolon through time by the methods of McFadden et al. (1984). No replicates were made of these observations, as explants from a given clone produce nearly identical patterns of colony ontogeny 

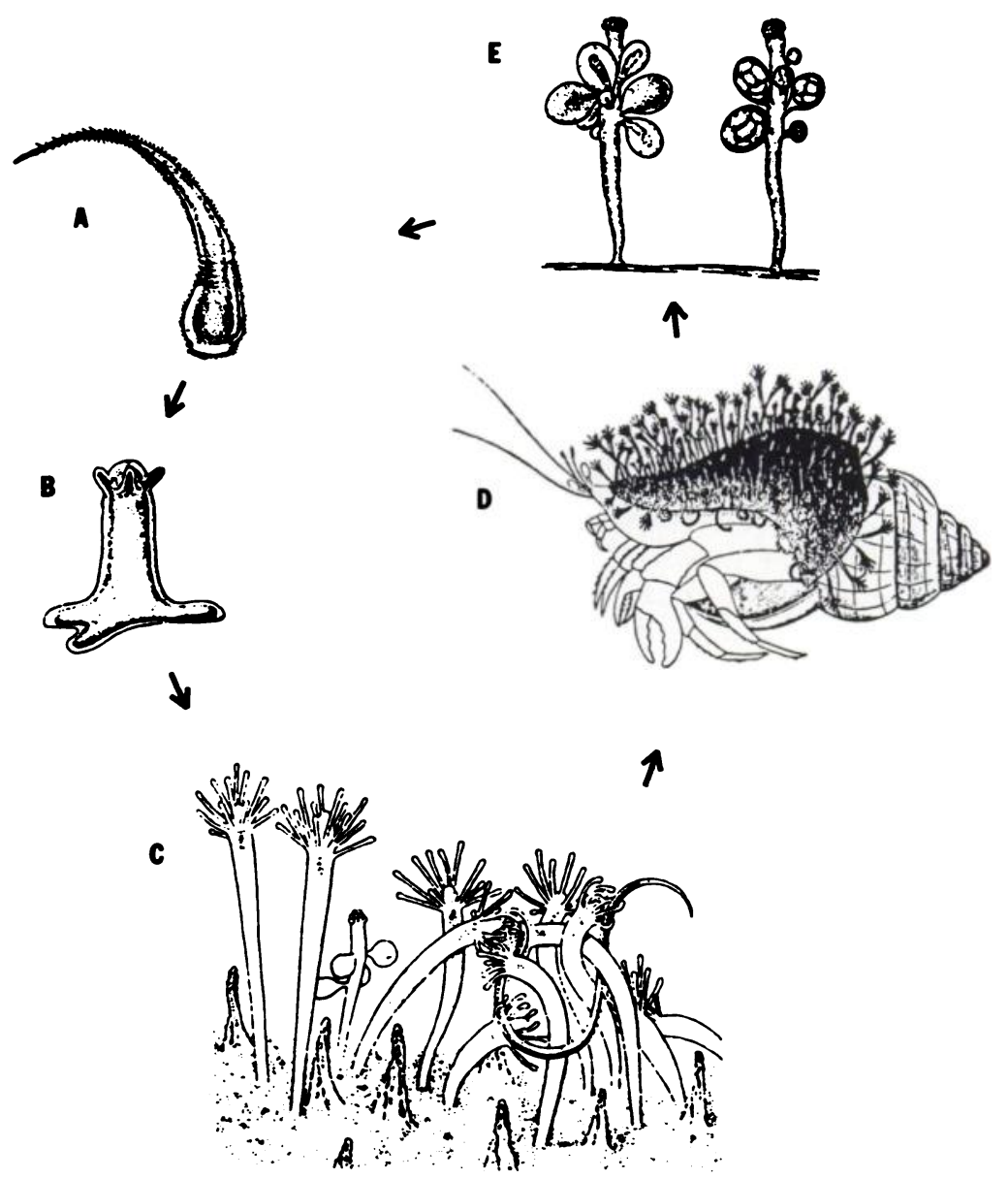

FIGURE 1. Life cycle of Hydractinia echinata. Fertilized egg develops into crawling planuloid larvae (A) which attaches to a substratum and metamorphoses into a primary polyp (B). By asexual iteration, this polyp develops into a mature colony $(C, D)$ which will produce either male or female reproductive polyps (E). (from McFadden et al., 1984).

(Buss and Grosberg, unpub.). Knowledge of the ontogenetic patterns allowed pairing of colonies at points in ontogeny such that all possible tissue interactions were observed in both isogeneic and allogeneic combinations. Each pairwise combination was replicated at least five times. Observations were made on the sequence of events following contact between colonies at 50X using a dissecting microscope.

\section{Ultrastructure of the fusion-rejection interaction}

Three categories of response to contact between colonies were noted using light microscopy: fusion, rejection with hyperplastic stolon formation, and rejection without hyperplastic stolon formation. The development of each of these three outcomes was examined using transmission electron microscopy. Explants of the appropriate colonies were attached to Lux petri dishes and fixed at various times after the initial contact between colonies. Colonies were fixed in modified Karnovsky's fixative (Karnovsky, 
1965) containing $2 \%$ paraformaldehyde, $2.5 \%$ gluteraldehyde, $1.5 \mathrm{M} \mathrm{CaCl}_{2}$ in $0.1 \mathrm{M}$

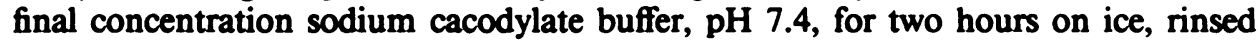
in buffer, then postfixed in $1 \% \mathrm{OsO}_{4}$ on $0.1 \mathrm{M}$ sodium cacodylate buffer for one hour on ice. Colonies were then rinsed in buffer, dehydrated through a graded series of ethanol dilutions, treated with propylene oxide, infiltrated, and flat-embedded in their original Lux permanox petri dishes in Polybed 812 polymerized at $60^{\circ} \mathrm{C}$ overnight. Colonies were separated from the dishes, cut out with a jewelers saw, and either (1) mounted onto a blank for face-on sectioning across histocompatibility interactions or (2) clamped directly into a LKB Huxley ultramicrotome for cross-sectioning. Areas of isogeneic and allogeneic tissue interactions were located via light microscopy by examining $1 \mu$ thick sections stained in $0.25 \%$ Azure I and $0.25 \%$ Azure II in $0.25 \%$ Sodium Borate. Once located, ultrathin sections from silver to light gold interference color were cut with a diamond knife and mounted on formvar coated $1 \times 2 \mathrm{~mm}$ slot grids, allowing direct correlation of both the thick section via light microscopy and the entire thin section via transmission electron microscopy. Following staining in 2\% Uranyl acetate in 50\% Ethanol for 15 minutes and Reynold's lead citrate for 60 seconds, sections were examined and photographed using either a Philips E.M. 200 or Philips E.M. 300 operated at $60 \mathrm{kV}$.

The development of hyperplastic stolons was also observed in scanning electron microscopy, to help correlate transmission microscopy results with observations made with the dissecting microscope. Colonies were grown on glass cover slips and fixed by the same protocol as those prepared for transmission electron microscopy. Following dehydration through a graded series of ethanol, samples were taken through critical point in liquid $\mathrm{CO}_{2}$ in a Sorvall critical point drying apparatus, and sputter coated with $60 \% \mathrm{Au}, 40 \% \mathrm{Pd}$. Samples on coverslips were examined and photographed using an ETEC autoscan scanning electron microscope operated at 5-10 kV.

\section{Interstitial cells and the development of hyperplastic stolons}

Colonies were experimentally deprived of interstitial cells (I-cells) to assess the potential influence of the induced differentiation of nematocytes in histocompatibility interactions. The I-cells of hydroids appear to be a multipotent stem cell line, capable of differentiating into any of the various somatic cell types (Lentz, 1966; Muller, $1967,1968)$. In the growing colony, however, I-cells only replace those cells incapable of mitotic activity: the nematocytes, the sensory-motor-interneurons, and the gametes (Diehl and Burnett, 1964, 1965a, b; Muller, 1964, 1967, 1968; Campbell and David, 1974; David and Murphy, 1977; Marcum and Campbell, 1978). In H. echinata, interstitial cells (I-cells) are located between gastrovascular canals within the mat and occur only rarely in the stolons (Muller, 1964).

Muller $(1967,1968)$ has demonstrated that application of mitomycin-C leads to the selective lysis of interstitial cells in $H$. echinata. Mitomycin-C acts primarily by attacking RNA synthesis and may secondarily lead to structural damage in DNA (Muller, 1967). Application of mitomycin-C leaves cnidoblasts, nerve cells, and epitheliomuscular cells intact and thus is preferable to the irradiation or nitrogen mustard techniques typically used with Hydra (Muller, 1967). Colonies exposed to mitomycin retain the ability to regenerate, produce new polyps, and elongate stolons. Treated colonies, however, can no longer differentiate nematocytes and will eventually die unless fed manually.

We experimentally eliminated the I-cell population of colonies to determine the capacity of I-cell-depleted organisms to recognize incompatible tissues and to mount a hyperplastic response. Three large colonies were exposed for 14 hours to $0.06 M$ 
mitomycin-C. Immediately following the mitomycin exposure, four explants from an isogeneic, but unexposed colony were placed into contact with one of the exposed colonies to determine whether the I-cell-depleted colony retained its fusibility characteristics and, if so, to repopulate the depleted colony with I-cells. After two weeks, four explants from this exposed-replenished colony were placed in contact with allogeneic tissue as controls for the exposure process. The second exposed colony was used to test the capacity of an I-cell-depleted colony to mount a hyperplastic response. Eleven explants of allogeneic tissues were placed in contact with the exposed colony and observations made on the behavior of stolons in contact. The third colony was left unmanipulated and died within three weeks, indicating that the I-cell population of the colony had been effectively eliminated.

\section{RESULTS}

\section{Colony ontogeny and histocompatibility}

The growth of polyps, mat, and stolon throughout ontogeny for the five genotypes are presented in Figure 2. The five strains differ significantly in the rate of growth of mat (ANOVA, F = 4.49, $P<0.01$ ), polyps (ANOVA, $\mathrm{F}=3.03, P<0.05$ ), and stolonal tissues (ANOVA, F $=5.58, P<0.005$ ). Log-transformed regressions of mat, polyp, and stolon tissues through time are presented in Table I. Inspection of Figure 2 illustrates that the five strains fall into three distinct groups. Strains 1 and 2 produce no stolons at any point in ontogeny, 4 and 5 produce stolons throughout ontogeny, and strain 3 only produces stolons late in ontogeny.

The histocompatibility responses of $H$. echinata were assessed in all paired combinations of the five strains (Fig. 3). In addition, strain 3 was paired with all other strains during both its early stolonless stage and late stoloniferous stage of ontogeny. Intraspecific contacts resulted in one of three unambiguous results: fusion, rejection without hyperplastic tissue formation, and rejection with hyperplastic tissue formation (Table II). Fusion is recognized by the disappearance of a discrete margin between tissues and the formation of a shared gastrovascular canal system (Fig. 4A). Rejection without hyperplasticity is recognized as the persistence of a discrete margin separating tissues in contact, with no evidence of shared gastrovascular systems (Fig. 4B). Rejection with hyperplasticity is recognized as the presence of swollen, erect stoloniferous tissues differentiating along, and extending atop, the contact zone (Fig. 4C, D).

Three relationships emerge from the results of paired histocompatibility interactions. First, all isogeneic combinations fuse and all allogeneic combinations reject (Table II). Second, fusion occurs in isogeneic crosses irrespective of the tissues which contact; whereas the pattern in rejection is dependent on the types of tissue which contact (Table II). Finally, mat and stolon tissue differ in their morphogenetic potential; only stolon can produce hyperplastic tissue. In allogeneic crosses, hyperplastic stolon is induced whenever stolons contact either foreign mat or stolon. Rejection without induction of hyperplasticity occurs only when foreign mats contact (Table II). It is important to note that strain 3 produced hyperplastic stolons in late ontogenetic encounters (i.e., stolon-mat contacts) and failed to do so in early ontogenetic encounters (i.e., mat-mat contacts), indicating that the different behavior of mat and stolonal tissues in histocompatibility interactions is purely a difference in the morphogenetic potential of the two tissue types.

\section{Ultrastructure of fusion and rejection response}

Contact between isogeneic tissues results in clear and unambiguous fusion between colonies of $H$. echinata. Fusion is recognized as the narrowing and rapid disappearance 


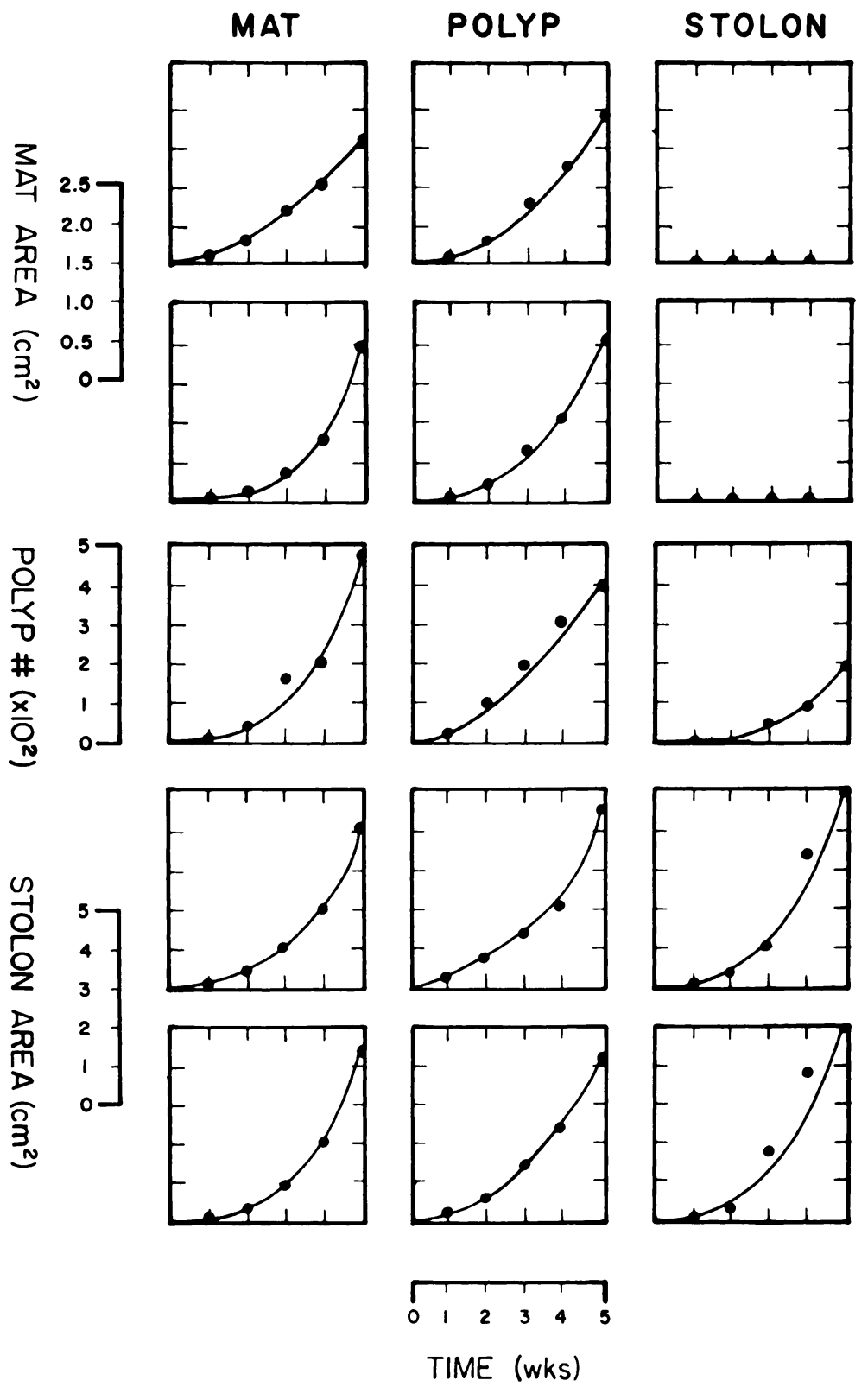

FIGURE 2. Colony ontogeny of the five genotypes of Hydractinia echinata used in studies of histocompatibility. Each row represents the growth for one genotype of mat area in $\mathrm{cm}^{2}$, of the number of polyps, and the enclosed area of stolons in $\mathrm{cm}^{2}$ versus time. Data for strains $1-5$ appear sequentially in row order from top to bottom. Scales are the same for each plot.

of the periderm coat in the region of contact immediately following contact between colonies. Ultrastructural observations show no evidence of any boundary between cells of the two colonies as early as 1.5 hours following the initial contact (Fig. 5a). Within four hours of the initial contact a shared gastrovascular system has become 
TABLE I

Colony ontogeny

\begin{tabular}{cccccccccc}
\hline \hline Strain & $\begin{array}{c}\text { Slope- } \\
\text { Mat }^{1}\end{array}$ & $\mathbf{R}^{2}$ & Signif. $^{2}$ & $\begin{array}{c}\text { Slope- } \\
\text { Polyp }^{1}\end{array}$ & $\mathbf{R}^{2}$ & Signif. $^{2}$ & $\begin{array}{c}\text { Slope- } \\
\text { Stolon }\end{array}$ & $\mathbf{R}^{2}$ & Signif. $^{2}$ \\
\hline 1 & $\mathbf{0 . 3 9 8}$ & .957 & $\boldsymbol{P}<0.001$ & $\mathbf{0 . 4 2 4}$ & .987 & $\boldsymbol{P}<0.001$ & - & - & - \\
2 & $\mathbf{0 . 5 6 8}$ & .988 & $\boldsymbol{P}<0.001$ & $\mathbf{0 . 3 9 7}$ & .999 & $\boldsymbol{P}<0.001$ & - & - & - \\
3 & $\mathbf{0 . 5 1 2}$ & .982 & $\boldsymbol{P}<0.001$ & $\mathbf{0 . 5 8 7}$ & .993 & $\boldsymbol{P}<0.001$ & .227 & .836 & $\boldsymbol{P}<0.05$ \\
4 & $\mathbf{0 . 5 4 9}$ & .990 & $\boldsymbol{P}<0.001$ & $\mathbf{0 . 7 3 4}$ & .948 & $\boldsymbol{P}<0.001$ & .387 & .963 & $\boldsymbol{P}<0.001$ \\
5 & $\mathbf{0 . 4 0 2}$ & .993 & $\boldsymbol{P}<\mathbf{0 . 0 0 1}$ & $\mathbf{0 . 4 8 1}$ & .936 & $\boldsymbol{P}<0.001$ & .301 & .969 & $\boldsymbol{P}<0.001$ \\
\hline
\end{tabular}

' Log (mat, stolon, polyp) versus log (time).

${ }^{2}$ F-test.

established, as evidenced in live observations by the movement of granular material from one colony into the other.

Rejection between allogeneic tissues is characterized by a distinct fibrous boundary separating the two colonies (Fig. 5b, c). This fibrous boundary appears distinct from the periderm coat, is secreted by both colonies, and occurs in both types of rejection responses. At no point have we seen any direct cell-to-cell contact between colonies, nor any evidence of either cells or vesicles crossing this boundary. It is important,

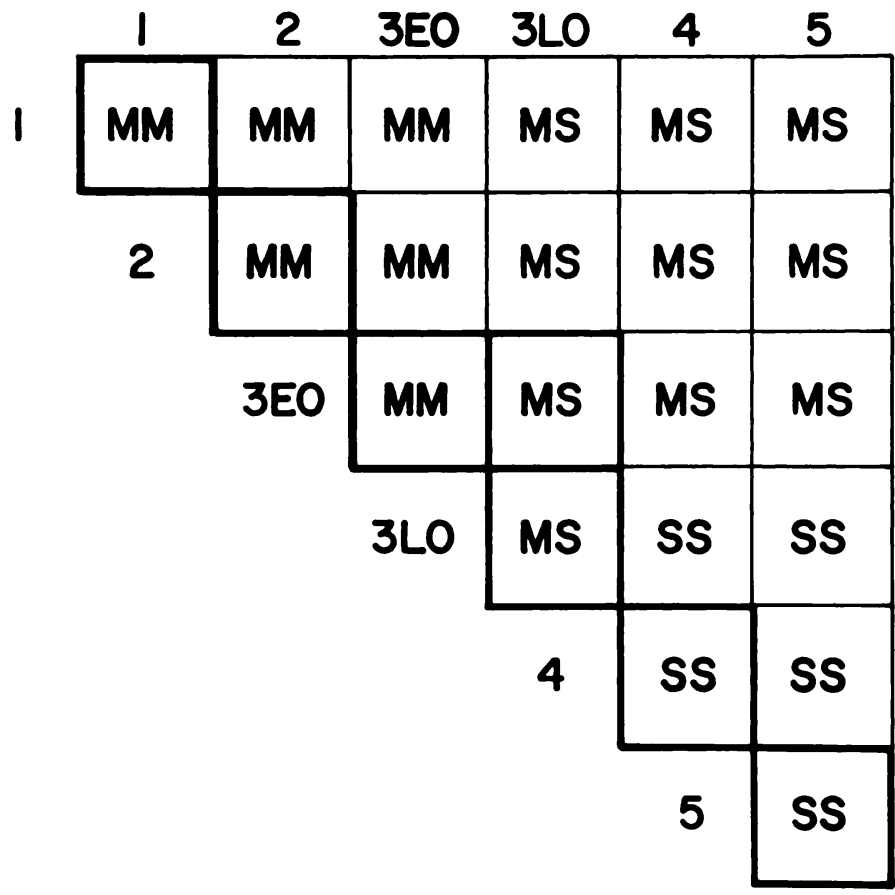

FIGURE 3. Matrix of the tissue interactions resulting from combinations of the five genotypes. Columns and rows represent strain numbers. Note that strain 3 was tested at two different times during ontogeny, during its early ontogenetic (3EO) stolonless phase and its late ontogeny (3LO) stoloniferous stage. Bold face cells represent isogeneic combinations, all other cells represent allogeneic interactions. Five replicates were made for each cell in this matrix. MM-mat versus mat interactions, MS-mat versus stolon interactions, and SS-stolon versus stolon interactions. 

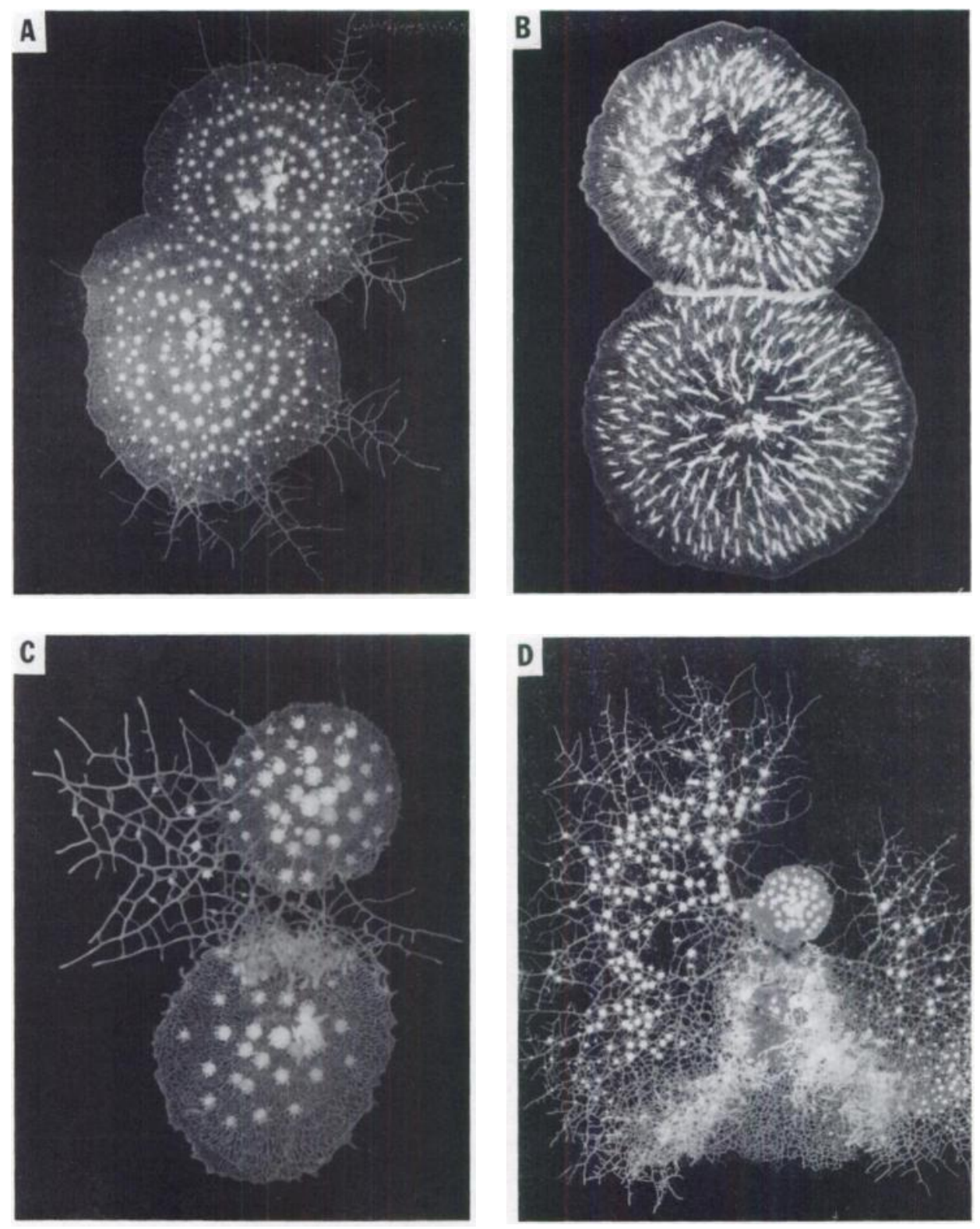

FIGURE 4. (A) Fusion between two colonies of Hydractinia echinata. Note the continuous gastrovascular canals traversing the margin between colonies. (B) Rejection between mats of two incompatible colonies. Note the failure to fuse along shared colony margin. (C) Rejection between a stolon producing colony and a colony which produces no stolons. Note development of hyperplastic stolons where stolons contact the mat of the foreign colony. (D) Rejection between two stolon producing strains, showing hyperplastic stolon development where stolons of the two colonies contact.

however, to recognize that microvillar extensions of ectodermal cells frequently perforate the mucous layer, hence direct cell surface communication is not ruled out by our observations. 
TABLE II

Histocompatibility interactions

\begin{tabular}{llccc}
\hline \hline & & & \multicolumn{2}{c}{ Rejection* } \\
\cline { 4 - 5 } Tissues in Contact & n & Fusion & $\begin{array}{c}\text { No Hyperplastic } \\
\text { Response }\end{array}$ & $\begin{array}{c}\text { Hyperplastic } \\
\text { Response }\end{array}$ \\
\hline A. Isogeneic Interactions & & & & \\
Mat versus Mat & 15 & 15 & 0 & 0 \\
Mat versus Stolon & 10 & 10 & 0 & 0 \\
Stolon versus Stolon & 10 & 10 & 0 & \\
& & & & $0-0$ \\
B. Allogeneic Interactions & & & & $0-40$ \\
Mat versus Mat & 15 & 0 & $15-15$ & $15-15$ \\
Mat versus Stolon & 40 & 0 & $40-0$ & $0-0$ \\
Stolon versus Stolon & 15 & 0 & &
\end{tabular}

- First figure represents behavior of first tissue type listed.

Rejection by mat and stolonal tissues differs fundamentally in that stolonal tissues undergo a complex series of morphogenetic transitions following contact with foreign tissue. Within 24 hours of the original contact, stolons become markedly swollen and begin to lose their periderm coat. These swollen or hyperplastic stolons lift up off the substratum and begin to redirect growth toward the foreign colony (Fig. 7a). Upon contacting the foreign tissue, the tissues underlying the stolon lyse. At the ultrastructural level, this series of events is recognized as the movement of numerous cnidoblasts and interstitial cells into the stolon, the development of a distinctive cnidom on the surface of the hyperplastic stolon coming into contact with the foreign tissue (Fig. 6a, b), and the discharge of numerous nematocysts of the basotrichious isorhizal type (Fig. 7c; Mariscal, 1974) into the foreign tissues and the associated lysis of cells in the region of contact (Fig. 6c, d, 7b).

\section{Rejection in I-cell-depleted colonies}

I-cell-depleted colonies retain their fusibility characteristics, fusing with isogeneic colonies $(n=4)$ and failing to fuse with allogeneic tissues $(n=11)$. I-cell-depleted colonies, however, failed to display a typical hyperplastic response. Upon contacting foreign tissue, stolons of I-cell-depleted colonies swelled very slightly. These stolons, however, failed to continue to swell in the typical fashion or to lift off the substratum and redirect growth toward the foreign colony. Exposed colonies with their I-cell population replenished $(n=4)$ displayed a wholly typical hyperplastic response to allogeneic tissues. These experiments demonstrate that the induction of hyperplasticity is dependent upon I-cells, but that the recognition of foreign tissue upon initial contact between colonies is not.

\section{Discussion}

The hyperplastic response of $H$. echinata to allogeneic tissue bears a number of similarities to anthozoan responses to neighbors. Both hydrozoan and anthozoan responses (1) require contact for induction; (2) are capable of discriminating between 

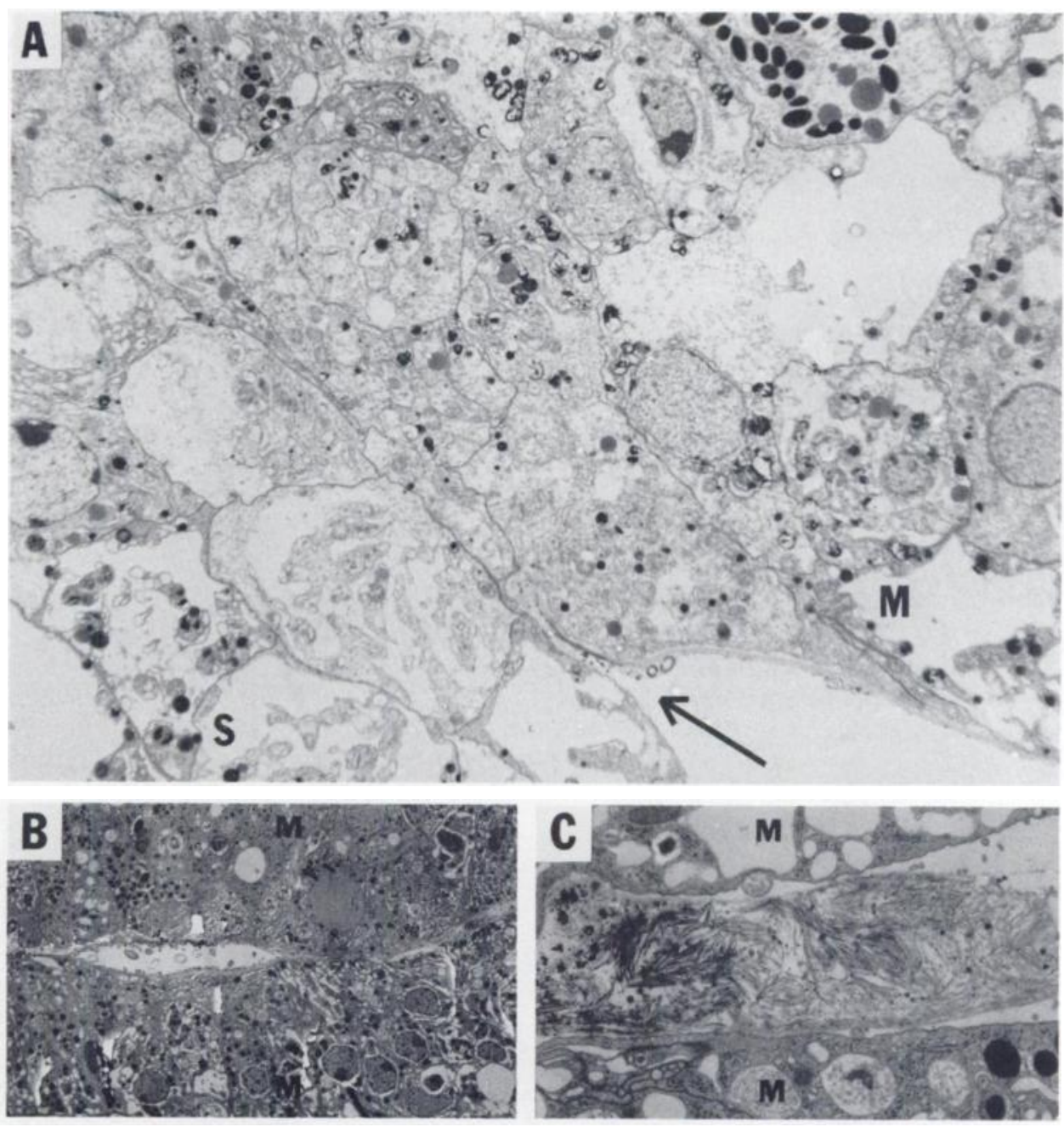

FIGURE 5. (A) Fusion of mat and stolonal tissues 1.5 hours after initial contact between colonies $(1390 \times)$. Arrow points to region of initial contact. Note the lack of any distinct boundary separating cells of the two colonies. (B) Rejection between mats of two allogeneic colonies (1200X). Lying between the two colonies, along the entire length of boundary, is an electron-dense fibrous material. This fibrous layer, shown at higher magnification $(8040 \times)$ in $(C)$, is not in contact with the tissues of either colony. $M=$ mat, $\mathbf{S}=$ stolon.

isogeneic and allogeneic tissues; (3) respond by site-specific cellular differentiation; and (4) involve the discharge of nematocysts to effect destruction of foreign tissues.

\section{Recognition elements}

Anthozoan responses to foreign tissues are apparently elicited by contact with either the tentacles, coenosarcs, or mesenterial filaments of other cnidarians. In $H$. echinata, the response is elicited following contact with either mat or stolonal tissue. Cnidarians are typically covered with a copious mucous layer, perforated with microvillar extensions of ectodermal cells. Tardent and Buhrer (1982) suggest that rec- 


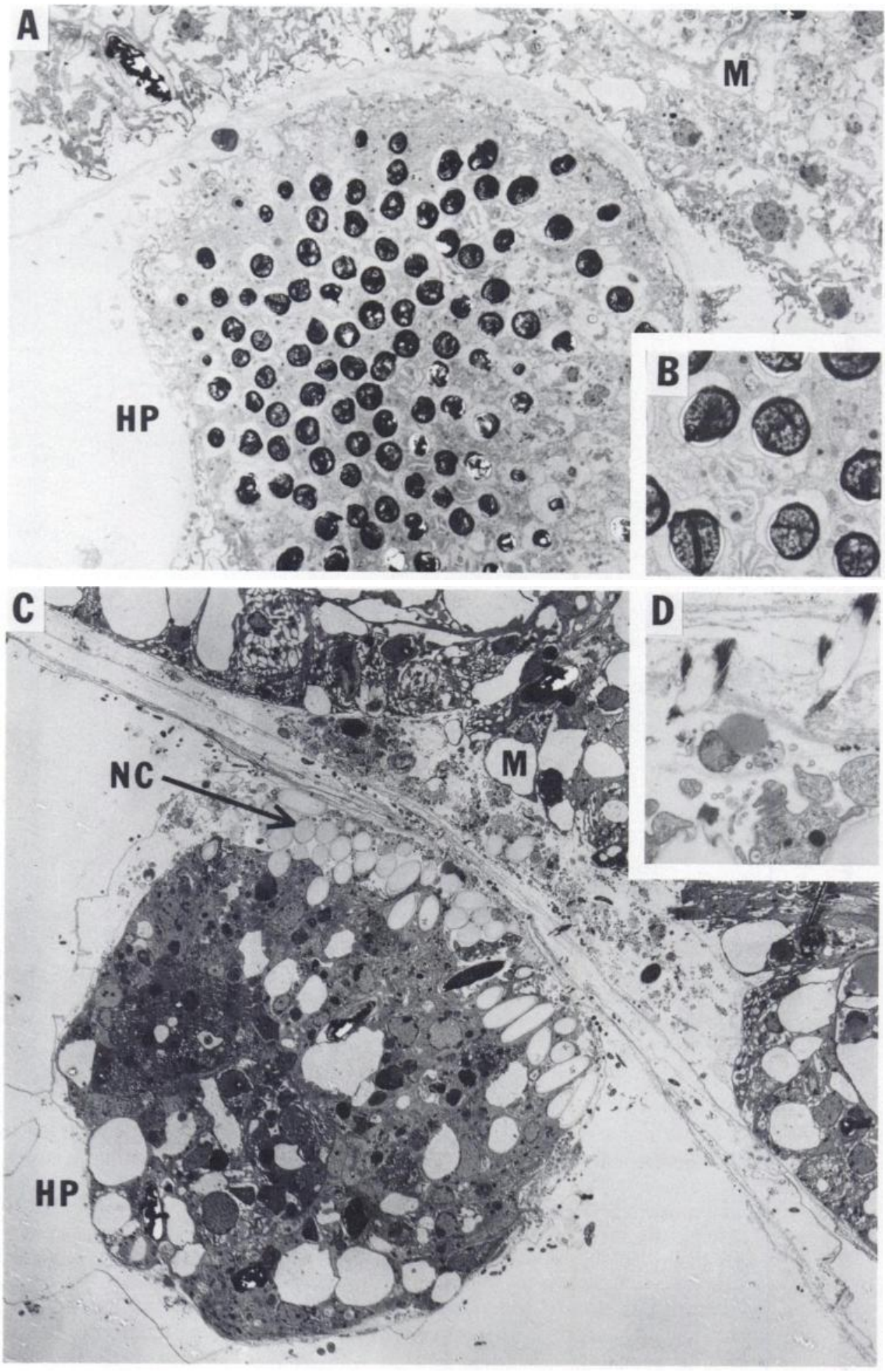


ognition elements lie within the mucous layer of Podocoryne carnea, but they do not consider the possible influence of cell-surface markers on ectodermal villi. Bigger (1976), however, tested the capacity of allogeneic mucus to elicit an acrorhagial response in Anthopleura krebsi and found no such effect. Lubbock (1979) demonstrated that mucous extractions of various sea anemone and coral species have markedly different antigenic determinants. He failed, however, to detect differing antigenic determinants in mucus within a given species. The localization and eventual characterization of recognition elements remains a central, unresolved issue.

\section{Historecognition}

A hallmark of anthozoan responses to neighboring cnidarians is the capacity to distinguish between isogeneic and allogeneic tissues and to selectively deploy effector systems against allogeneic forms. To my knowledge, all substratum-bound cnidarians investigated are able to distinguish between isogeneic and allogeneic tissues (Table III). In contrast to the apparent uniformity of allorecognition, cnidarian recognition of xenogeneic tissues is quite variable. Several anemones fail to display acrorhagial responses upon interspecific encounters with other anemones (Francis, 1973; Bigger, 1976, 1980; Williams, 1978), despite the ability of at least one anemone to recognize tissues as different as that of a scyphozoan medusae (Bigger, 1976, 1980). Similarly, catch tentacle development in Metridium senile may vary greatly in both occurrence and effect on other anemones (Purcell and Kitting, 1982). Among scleractinians, sweeper tentacles in Agaricia agaricities may develop in response to encounters with the encrusting gorgonian Erythropodium caribaeoreum and the zooanthid Palythoa caribbea (Chornesky, 1983). Similarly, the hydrocoral Millepora dichotoma displays varying degrees of interspecific aggression in response to xenogeneic neighbors (Muller et al., 1983).

The apparent ubiquity of allorecognition may reflect a primitive capability of cnidarians and the variability in deployment of effector systems in xenogeneic encounters may be a relatively recent adaptation to local circumstances. If this hypothesis is correct, xenogeneic effector systems should be found most frequently between species in which the frequency and potential severity of interspecific encounters is great. This suggestion is tentatively supported by observations of the interactions among hydractiniid hydroids in Long Island Sound. Hydractinia echinata is the most common hydractiniid and interactions are primarily intraspecific contacts, whereas Podocoryne carnea is relatively rare and makes frequent interspecific encounters (Buss and Yund, unpub.). As expected, $P$. carnea is capable of mounting a sustained hyperplastic response to $H$. echinata, whereas $H$. echinata is incapable of maintaining a similar response to $P$. carnea (McFadden, unpub.). Further study of the relationship between the occurrence of xenogeneic effector systems and the relative frequency of intraspecific and interspecific competition is warranted.

FIGURE 6. (A) Section across the tip of a hyperplastic stolon in contact with foreign mat $(800 \times)$. Note high density of nematocysts in hyperplastic stolon. 96 hours after initial contact between colonies. (B) Inset of this cross-section in higher magnification (3273X), shows that each cell harbors a nematocyst. (C) Section across hyperplastic stolon in contact with foreign mat $(800 \mathrm{X})$. Note the concentration of capsules of discharged nematocysts along the margin of the hyperplastic stolon where it is in contact with foreign tissue and the zone of destruction directly underlying this region. These discharged capsules are eventually sloughed off, a new set of nematocytes are differentiated, and the interaction repeated until the foreign tissue is completely eliminated. (D) Inset shows the contact zone at greater magnification (3273X), showing shafts of the nematocysts embedded in the foreign tissue. HP = hyperplastic stolon, $M=$ mat, NC = nematocyst capsule. 

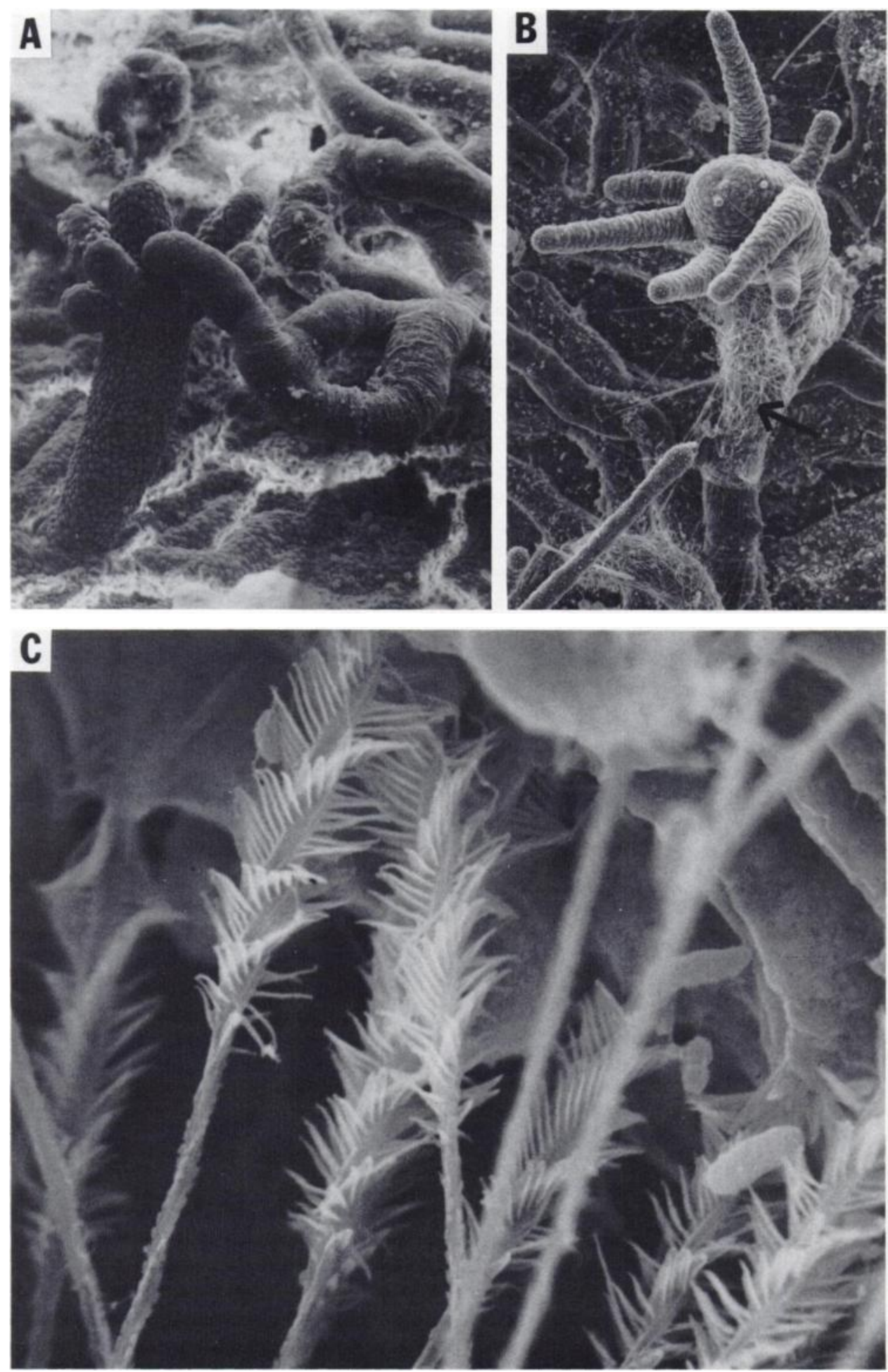
TABLE III

Cnidarian histocompatibility and competition

\begin{tabular}{|c|c|c|}
\hline Taxon & Effector System & References \\
\hline \multicolumn{3}{|l|}{ Hydrozoa } \\
\hline Hydractinia echinata & Hyperplastic stolons & $\begin{array}{l}\text { Schijfsma, 1939; Muller, 1964; Ivker, } \\
1972\end{array}$ \\
\hline Podocaryne carnea & Hyperplastic stolons & Tardent and Buhrer, 1982 \\
\hline \multicolumn{3}{|l|}{ Milleporina } \\
\hline Millepora dichotoma & Unknown & Muller et al., 1983 \\
\hline \multicolumn{3}{|l|}{ Anthozoa } \\
\hline \multicolumn{3}{|l|}{ Gorgonacea } \\
\hline Lophogorgia sarmentosa & Unknown & Theodor, 1970 \\
\hline Eunicella stricta & Unknown & Theodor, 1976 \\
\hline Leptogorgia virgulata & Unknown & Bigger and Runyan, 1979 \\
\hline Psuedopterogorgia elisabethae & Unknown & Bigger and Runyan, 1979 \\
\hline Plexaura flexuosa & Unknown & Bigger and Runyan, 1979 \\
\hline \multicolumn{3}{|l|}{ Actiniaria } \\
\hline Actinea equina & Acrorhagi & Francis, 1973b, Brace and Pavey, 1978 \\
\hline Anthopleura artemisia & Acrorhagi & Bigger, 1980 \\
\hline A. balloii & Acrorhagi & Williams, 1978 \\
\hline A. elegantissima & Acrorhagi & Francis, 1973b \\
\hline A. Krebsi & Acrorhagi & Bigger, 1976, 1980 \\
\hline Anemonia sargassensis & Acrorhagi & Bigger, 1980 \\
\hline Bunodosoma cauernata & Acrorhagi & Bigger, 1980 \\
\hline Phymactis clematis & Acrorhagi & Brace, 1981 \\
\hline Cereus pendunculatus & Catch Tentacles & Williams, 1975 \\
\hline Diadumene cincta & Catch Tentacles & Williams, 1975 \\
\hline Halipanella luciae & Catch Tentacles & $\begin{array}{l}\text { Williams, 1975; Watson and Mariscal, } \\
1983\end{array}$ \\
\hline Metridium senile & Catch Tentacles & Purcell, 1977 \\
\hline Sargartia elegans & Catch Tentacles & Williams, 1975 \\
\hline S. troglodytes & Catch Tentacles & Williams, 1975 \\
\hline \multicolumn{3}{|l|}{ Scleractinia } \\
\hline Agaricia agaricites & Sweeper Tentacles & Chornesky, 1983 \\
\hline Montastrea cavernosa & Sweeper Tentacles & Richardson et al., 1979 \\
\hline Montipora verrucosa & Unknown & Hildeman et al., 1975, 1980 \\
\hline $\begin{array}{l}\text { Pocillopora damicornis } \\
\text { P. robusta }\end{array}$ & $\begin{array}{l}\text { Sweeper Tentacles } \\
\text { Sweeper Tentacles }\end{array}$ & $\begin{array}{l}\text { Wellington, } 1980 \\
\text { Wellington, } 1980\end{array}$ \\
\hline
\end{tabular}

\section{Site-specific differentiation}

The occurrence of such a diverse array of responses to foreign tissues testifies to the chronic occurrence of intra- and interspecific competition in cnidarians. Contacts between cnidarians are typically site-specific; interactions among scleractinians and

FIGURE 7. (A) Scanning electron micrograph showing a hyperplastic stolon arching off the substratum toward a polyp of an allogeneic colony (120X). (B) Contact between a hyperplastic stolon (arrow) and a foreign polyp $(190 \mathrm{X})$. Note the concentration of nematocysts threads where hyperplastic stolon contacts the foreign polyp. (C) Artificially discharged nematocysts from a hyperplastic stolon (440X), showing these nematocysts to be basotrichious isorhizas. 
hydrozoans are typically made only along colony margins and interactions between anemones are often limited to only a portion of a clonal patch. Several cnidarian responses to foreign tissues (e.g., sweeper tentacles, catch tentacles, hyperplastic stolons) share a common feature: the capacity for site-specific differentiation of specialized tissues and morphologies. The capacity for site-specific differentiation is enormously important as it allows a colony to divert energies to aggression only in those tissues where they may be most effective. Site-specific differentiation, however, can only occur if the group is capable of transporting multipotent stem cells (or their products) to the zone of combat. This trait is limited in phyletic distribution; only sponges, cnidarians, platyhelminthes, echinoderms, and chordates have been found to possess a mitotically active multipotent stem line throughout ontogeny (Nieuwkoop and Sutasurya, 1981; Buss, 1983a, b).

The dependence of several effector systems on site-specific differentiation underscores the need for caution in the interpretation of immunologic "memory" in invertebrates. The repeated reports of memory in invertebrates involve systems in which the effector mechanisms are unknown (Hildeman, 1975, 1977a, b, 1980; Manning, 1980; Bigger et al., 1982). However, if these responses require differentiation of multipotent stem cells the observation of memory may simply reflect the deployment of specialized cells or cell products the differentiation of which had been previously induced. Although this will result in an accelerated second-set response, this observation does not imply that (a) the putative memory will be retained over ecologically relevant time scales or that (b) the accelerated second-set response will be observed to display any specificity whatsoever with respect to antigenic determinants. In the absence of a detailed knowledge of the nature of the effector system and appropriate third party experiments, the observation of an accelerated second-set response cannot be considered evidence of existence of a memory component homologous to that of vertebrate immune systems.

\section{Effector systems}

Perhaps the most striking similarity between the various groups of cnidarian responses to foreign tissues is the evolution of a nematocyst-based effector system. Nematocyst function is remarkable in its evolutionary lability; various specialized nematocysts are used for attachment, prey immobilization, prey capture, and clone defense (Mariscal, 1974). Nematocysts appear in structures as different and as limited in phyletic distribution as scleractinian sweeper tentacles and mesenterial filaments (den Hartog, 1977; Wellington, 1980), actinarian catch tentacles (Calgren, 1929; Hand, 1955; Williams, 1975; Purcell, 1977; Watson and Mariscal, 1982) and acrorhagia (Calgren, 1949; Abel, 1954; Bonnin, 1964; Francis, 1973b), and hydroid hyperplastic stolons (Figs. 6,7). The use of nematocysts in histocompatibility and competition is likely a convergence in function.

\section{Evolution of histocompatibility}

The similarity of anthozoan and hydrozoan responses to foreign tissue suggests the need to distinguish between selection for histocompatibility and selection for competitive ability. Several authors have suggested that competition between individuals (or species) was the primitive selective agent shaping the evolution of allorecognition (e.g., Kaye and Ortiz, 1981). This hypothesis seems unlikely for two reasons. It is difficult to understand how a diversity of different competitive behaviors and structures could have evolved if there were not a pre-existing system allowing for the recognition of those individuals and species against which they might be effective. In addition, cnidarians are uniformly capable of recognizing allogeneic tissues, 
even in forms in which competition between conspecifics seems highly unlikely. A more parsimonious explanation is that genes for historecognition and totipotent cells capable of differentiating into nematocysts were ancestral features of cnidarians which became linked into certain groups. The diversity of cnidarian responses to competition may ultimately reflect the co-occurrence in this group of (1) a primitive system of historecognition, (2) a mitotically active multipotent stem cell lineage, and (3) an effective device, the nematocyst, which might be coopted to defensive functions. If this is the case, selective forces other than competition between individuals must account for the evolution of historecognition.

A frequently cited alternative explanation for the evolution of histocompatibility is that of defense against microbial and viral infections, cancer, and pathogen mimicry ("surveillence theory," e.g., Burnet, 1970). Although microbial infections are undoubtedly of considerable importance, there is little data upon which to assess this theory in cnidarians. Allorecognition might, for example, be interpreted as a defense against the potential of fusion acting as a vector for pathogens. However, nematocystbased effector systems are clearly unsuitable for employment against pathogens. Nematocysts are an order of magnitude larger than microbes and their unique method of deployment is clearly unrelated to any microbial clearance function. Cnidarians, however, may not be limited to nematocyst-based effector systems. For example, certain classes of cellular (Hildemann, 1975, 1977a, b) or allelochemic (Sammarco et al., 1983) interactions have been suggested. Adequate assessment of the relevance of the "surveillence theory" to allorecognition in cnidarians must await further information on their mechanisms of microbial detection and clearance.

An alternative, but complementary, explanation for the evolution of histocompatibility is the somatic cell parasitism hypothesis (Buss, 1982). This hypothesis is based on the fact that the primordial germ cells of certain simple metazoans are not sequestered in early ontogeny. Fusion between conspecifics results in the passage of totipotent cells (i.e., competent to produce gametes) from one individual into another. If the totipotent cells of one individual prove more effective in differentiating into gametes than do those of the other component of the chimera, then one individual has effectively parasitized the other (Buss, 1982). Fusion between individuals with an active totipotent cell lineage produces a chimera in which the fitness of the components of the chimera is determined not only by the fitness of the chimeric individual relative to other individuals in the population, but also by competition between components of the chimera for representation in the gametes. Systems of allorecognition serve to prevent fusion and the subsequent invasion of the totipotent cell line of one individual into another, hence acting to defend an organism from somatic cell parasitism. If this scenario is correct, the totipotency of cell lines provides both the raison d'etre for the evolution of historecognition and the mechanism permitting the subsequent evolution of specialized competitive mechanisms in the Cnidaria.

\section{ACKNOWLEDGMENTS}

We thank K. Carle, E. Chornesky, D. Green, R. Grosberg, B. Keller, C. Wahle, and $P$. Yund for comments on the manuscript, and R. Lerner and T. Jenkin for technical assistance. Support was provided by the National Science Foundation (OCE8117695 and PCM-8310704).

\section{LITERATURE CITED}

ABEL, E. F. 1954. Ein Beitrag zur Giftwirkung der Actinien und Function der Randsackchen. Zool. Anz. 153: 259-268. 
BIGGER, C. H. 1976. The acrorhagial response in Anthopleura krebsi: intraspecific and interspecific recognition. Pp. 127-136 in Coelenterate Ecology and Behavior, G. O. Mackie, ed. Plenum Press, New York.

BIGGER, C. H. 1980. Interspecific and intraspecific acrorhagial aggressive behavior among sea anemones: a recognition of self and not-self. Biol. Bull. 159: 117-134.

BIGGER, C. H., AND RUNYAN, R. 1979. An in situ demonstration of self-recognition in gorgonians. Dev. Comp. Immnol. 3: 591-597.

BIGGer, C. H., P. L. JokIEL, W. H. Hildeman, AND I. S. JohNSTON. 1982. Characterization of alloimmune memory in a sponge. J. Immunol. 129: 1570-1572.

BonNin, J. P. 1964. Recherches sur la 'reaction d'aggression' et sur le fonctionnement des acorhages d'Actinia equina L. Bull. Biol. Fr. Belg. 1: 225-250.

BRACE, R. C. 1981. Intraspecific aggression in the colour morphs of the anemone Phymactis clematis from Chili. Mar. Biol. 64: 85-93.

BRACE, R. C., AND J. PAVEY. 1978. Size-dependent dominance hierarchy in the anemone Actinia equina. Nature 273: 752-753.

BRACE, R. C., J. PAVEY, AND D. L. J. QUICKIE. 1979. Intraspecific aggression in the color morphs of the anemone Actinia equina: the convention governing dominance ranking. Anim. Behav. 27: 553561.

Burnet, M. 1970. Self and Not-Self. Cambridge Univ. Press, Cambridge. 318 pp.

BUSS, L. W. 1982. Somatic cell parasitism and the evolution of somatic tissue compatibility. Proc. Natl. Acad. Sci. U.S.A. 79: 5337-5341.

BuSS, L. W. 1983a. Evolution, development and the units of selection. Proc. Natl. Acad. Sci. U.S.A. 80: 1387-1391.

BUSS, L. W. 1983b. Somatic variation and evolution. Paleobiology. 9: 12-16.

CALGREN, O. 1929. Uber eine Actiniariengattung mit besonderen Fangtentakeln. Zool. Anz. 81: 109-113.

CAMPBell, R. D., AND DAVID, C. N. 1974. Cell cycle kinetics and development of Hydra attenuata. II. Interstitial cells. J. Cell. Sci. 16: 349-358.

CHIBA, Y., AND M. KATO. 1966. Interspecific relation in the colony formation among Bougainvillia sp. and Cladonema radiatum (Hydrozoa, Coelenterata). Sci. Rep. Tohoku Univ. Ser. IV (Biol.) 32: 201-206.

CHORNESKY, E. A. 1983. Induced development of sweeper tentacles on the reef coral Agaricia agaricites: a response to direct competition. Biol. Bull. 165: 569-581.

CrOWELl, S. 1950. Individual specificity in the fusion of hydroid stolons and the relationship between stolonic growth and colony growth. Anat. Rec. 108: 560-561.

DAvID, C. N., AND S. MURPHY. 1977. Characteristics of interstitial stem cells in Hydra. Dev. Biol. 58: 372-383.

DiEHL, F. A., AND A. BURNETT. 1964. The role of interstitial cells in the maintenance of hydra. I. Specific destruction of interstitial cells in normal, asexual, non-budding animals. J. Exp. Zool. 155: 253260.

DiehL, F. A., AND A. BURNeTt. 1965a. The role of interstitial cells in the maintenance of hydra. II. Budding. J. Exp. Zool. 158: 283-298.

DIEHL, F. A., AND A. BURNETT. 1965b. The role of interstitial cells in the maintenance of hydra. III. Regeneration of hypostome and tentacles. J. Exp. Zool. 158: 299-318.

FranCIS, L. 1973a. Clone specific segregation in the sea anemone Anthopleura elegantissima. Biol. Bull. 144: 64-72.

FRANCIS, L. 1973b. Interspecific aggression and its effects on the distribution of Anthopleura elegantissima and some related sea anemones. Biol. Bull. 144: 73-92.

FRANCIS, L. 1976. Social organization within clones of the sea anemone Anthopleura elegantissima. Biol. Bull. 150: 361-376.

GALlien, L., AND M. C. GOUERE. 1974. Incompatibilite entre cultures inergeneriques d'explants chez hydraires Hydractinia echinata Fleming et Podocoryne carnea Sars. Comptes. r. hebd. Seane. Acad. Paris Ser. D. 278: 107-110.

GLYNN, P. W. 1976. Some physical and biological determinants of coral community structure in the eastern Pacific. Ecol. Mongr. 46: 431-456.

HAND, C. 1955. The sea anemones of Central California, Part III. The acontiarian anemones. Wasmann J. Biol. 13: 189-251.

DEN HARTOG, J. C. 1977. The marginal tentacles of Rhodactis sanctithomae (Corallimorpharia) and the sweeper tentacles of Montastrea cavernosa (Scleractinia); their cnidom and possible function. Pp. 463-469 in Proc. Third. Int. Coral Reef Symp., D. L. Taylor, ed. Univ. of Miami Press, Coral Gables.

HAUENSCHILD, V. C. 1954. Genetische und entwichlungphysiologische Untersuchungen uber Intersexualitat und Gewebevertraglichkeit bei Hydractinia echinata Flem. Wilhelm Roux Arch. Entwicklungsmech. Org. 147: $1-41$. 
HAUENSCHILD, V. C. 1956. Uber die Vererbung einer Gewebevertraglichkeits-Eigenschaft bei dem Hydroidpolypen Hydractinia echinata. Z. Naturforsch. 11b: 132-138.

Hildeman, W. H., D. S. LINTHICUM, AND D. C. VANN. 1975. Transplantation and immunoincompatibility reactions among reef-building corals. Immunogenetics 2: 269-284.

Hildeman, W. H., R. L. Raison, G. Cheung, C. J. Hull, L. Akaka, and J. Okamoto. 1977a. Immunological specificity and memory in a scleractinian coral. Nature 270: 219-223.

Hildeman, W. H., R. L. Raison, C. J. Hull, L. Akaka, J. Okumoto, and G. Cheung. 1977b. Tissue transplantation immunity in corals. Pp. 537-543 in Proc. Third Int. Coral Reef Symp., D. L. Taylor, ed. Univ. of Miami Press, Coral Gables.

Hildeman, W. H., P. L. JokiEl, C. H. BigGer, AND I. S. Johnston. 1980. Allogeneic polymorphism and alloimmune memory in the coral, Montipora verrucosa. Transplantation 30: 297-301.

IVKER, F. B. 1972. A hierarchy of histo-incompatibility in Hydractinia echinata. Biol. Bull. 143: 162-174.

KARNOVSKY, M. J. 1965. A formaldehyde-gluteraldehyde fixative of high osmolality for use in electron microscopy. J. Cell. Biol. 27: 137A-138A.

KATO, M., K. NAKAmURA, E. HiRA, AND Y. KAKINUmA. 1962. Interspecific relation in the colony formation among some hydrozoan species. Bull. Mar. Bio. St. Asamushi. Tohoku Univ. 11: 31-36.

KATO, M., E. HIRAI, AND Y. KAKINUMA. 1963. Further experiments on the interspecific relation in the colony formation among some hydrozoan species. Sci. Rep. Tohoku Univ. Ser. IV (Biol.) 29: 317-325.

KATO, M., E. HiRAI, AND Y. KAKINUMA. 1967. Experiments on the coaction among hydrozoan species in the colony formation. Sci. Rep. Tohoku Univ. Ser. IV (Biol.) 33: 359-373.

KAYE, H., AND T. ORTIZ. 1981. Strain specificity in a tropical marine sponge. Mar. Biol. 63: 165-173.

LANG, J. C. 1971. Interspecific aggression by scleractinian corals I. the rediscovery of Scolymia cubensis (Milne Edwards and Haime). Bull. Mar. Sci. 21: 952-959.

LANG, J. C. 1973. Interspecific aggression by scleractinian corals II. Why the race is not always to the swift. Bull. Mar. Sci. 23: 260-279.

LENTZ, T. L. 1966. The Cell Biology of Hydra. North-Holland Publ. Co., Amsterdam. 199 pp.

LUBBOCK, R. 1979. Mucous antigenicity in sea anemones and corals. Hydrobiologia. 66: 3-6.

MANNING, M. 1980. Phylogeny of Immunological Memory. Elsevier, New York. 359 pp.

MCFADDEN, C. S., M. MCFARLAND, AND L. W. BusS. 1984. Biology of hydractiniid hydroids. I. Colony ontogeny in Hydractinia echinata. Bio. Bull. 166: 54-67.

Mariscal, R. N. 1974. Nematocysts. Pp. 129-178 in Coelenterate Biology: Reviews and Perspectives, L. Muscatine and H. M. Lenhoff, eds. Academic Press, New York.

MARCUM, B. A., AND R. D. CAMPBell. 1978. Development of $H y d r a$ lacking nerve and interstitial cells. J. Cell Sci. 29: 17-33.

MULLER, W. E. G. 1964. Experimentelle Untersuchungen uber Stockentwicklung, Polypendifferenzierung und sexual Chimaren bei Hydractina echinata. Wilhelm Roux' Arch. Entwicklungsmech. Org. 155: 181-268.

MULLER, W. E. G. 1967. Differenzierungspotenzen und Geschlechtstabilitat der I-Zellen von Hydractinia echinata. Wilhelm Roux Arch. Entwicklungsmech. Org. 159: 412-432.

MULLER, W. E. G. 1968. Elimination der I-Zellen durch alkylierende Cytostatika und deren Effekte auf die Embryonalentwicklung bei Hydractinia echinata. Exp. Cell. Res. 49: 448-458.

MUller, W. E. G., A. MAIDHOF, R. K. ZAHN, AND I. MULleR. 1983. Histocompatibility reactions in the hydrocoral Millepora dichotoma. Coral Reefs 1: 237-241.

NieUWKOOP, P. D., AND L. A. SUTASURYA. 1981. Primordial Germ Cells in the Invertebrates. Cambridge Univ. Press, Cambridge.

OTtawaY, J. R. 1978. Population ecology of the intertidal anemone Actinia tenebrosa. I. Pedal locomotion and intraspecific aggression. J. Mar. Freshwater Res. 29: 787-802.

PURCELL, J. E. 1977. Agressive function and induced development of catch tentacles in the sea anemone Metridium senile (Coelenterata, Actiniaria). Biol. Bull. 153: 355-368.

PURCELL, J. E., AND C. L. KITTING. 1982. Intraspecific aggression and population distribution of the sea anemone Metridium senile. Biol. Bull. 162: 345-359.

REYNOLDS, E. S. 1963. The use of lead citrate at high pH as an electron-opaque stain in electron microscopy. J. Cell. Biol. 17: 208-212.

Richardson, C. A., P. DUSTAN, AND J. C. LANG. 1979. Maintenance of the living space by sweeper tentacles of Montastrea cavernosa. Mar. Biol. 55: 181-186.

Sammarco, P. W., J. C. Coll, S. LaBarre, and B. Willis. 1983. Competitive strategies of soft corals (Coelenterata:Octocorallia): allelopathic effects on selected scleractinian corals. Coral Reefs 1: 173-178.

SChufSMA, K. 1939. Preliminary notes on early stages in the growth of colonies of Hydractinia echinata (Flem.). Arch. Neerland. Zool. 4: 93-102. 
SHEPPARD, C. R. C. 1979. Interspecific aggression between reef corals with reference to their distribution. Mar. Ecol. Prog. Ser. 1: 237-247.

TARDENT, P., AND M. BUHRER. 1982. Intraspecific tissue incompatibilities in the metagenetical Podocoryne carnea M. Sars (Cnidaria:Hydrozoa). Pp. 295-303 in Embryonic Development, Part B. Cellular Aspects, M. M. Burger and R. Weber, eds. A. R. Liss, New York.

TeIssier, G. 1929. L'Origine multiple de certaines colonies d'Hydractinia echinata (Flem.) et ses consequences possibles. Bull. Soc. Zool. Fr. 54: 645-647.

THEODOR, J. L. 1970. Distinction between 'self' and 'not-self' in lower invertebrates. Nature 227: 690692.

THEODOR, J. L. 1976. Histocompatibility in a natural population of gorgonians. Zool. J. Linn. Soc. 58: 173-176.

TheOdOR, J. L., AND R. SENELAR. 1975. Cytotoxic interaction between gorgonian explants: mode of action. Cell. Immunol. 19: 194-200.

TOTH, S. E. 1967. Tissue compatibility in regenerating explant from the colonial marine hydroid Hydractinia echinata. J. Cell Physiol. 69: 125-131.

WATSON, G. M., AND R. N. MARISCAL. 1983. The development of a sea anemone tentacle specialized for aggression: morphogenesis and regression of the catch tentacle of Haliplanella luciae (Cnidaria, Anthozoa). Biol. Bull. 164: 506-517.

Wellington, G. M. 1980. Reversal of digestive interactions between Pacific reef corals: mediation by sweeper tentacles. Oecologia 47: 340-343.

Williams, R. B. 1975. Catch-tentacles in anemones: occurrence in Haliplanella luciae (Verill) and a review of current knowledge. J. Nat. Hist. 9: 241-248.

Williams, R. B. 1978. Some recent observations on the acrorhagi of sea anemones. J. Mar. Biol. Assoc. U.K. 58: 787-788.

Williams, R. B. 1980. A further note on catch tentacles in anemones. Trans. Norfolk Norwich Nat. Soc. 25: 84-86. 